\title{
Perception of Community Health Workers in Indonesia toward Patients with Mental Disorders
}

\author{
Shanti Wardaningsih ${ }^{1}$, Takayuki Kageyama ${ }^{2}$ \\ ${ }^{1}$ Department of Psychiatric Nursing , Univeristy of Muhammadiyah Yogyakarta, Indonesia \\ ${ }^{2}$ Department of Psychiatric Nursing, Oita University of Nursing and Health Sciences, Japan
}

\section{Article Info \\ Article history: \\ Received Sep 03, 2015 \\ Revised Dec 21, 2015 \\ Accepted Jan 25, 2016}

\section{Keyword:}

Community Health Worker

Kader

Mental Disorder

Perception

\begin{abstract}
In Indonesia, there are any community health volunteers called Kader. Although Kaders are members of mental health volunteer, they sometimes show negative attitude to psychotic persons, even they have already got some training about mental health. The aims of this study were to investigate 1) how is Kaders's perception compare to the other countries, 2) how will they consult compare to the other countries 3) how is comparison of Kaders' perception to mental disorder person between trained and untrained,. The method of this research is a descriptive explorative using survey study. This study was held on June to September 2013. It was conducted in five districts of Yogyakarta area with 619 respondents. The Questionnaires used contained three sections are follows; Part A is about Demographic Data, Part B two case vignettes (taken from MacArthur Health Module of the 1996 general Social Survey) and Part C about Kaders experiences. The perception of Kader as part of the community is lower than the general residence in the United States and Japan. The comparison between trained and untrained Kaders shown that trained Kaders has better perception toward patient with mental disorder. These results suggest that actual experiences in meeting the cases contributed to the improvement of Kaders' perception better than the previous mental health training did. It might be Kaders with short experience are explored information Kaders should be trained with more structured curriculum and recruiting Kader is recommended to recruit the young generation.
\end{abstract}

Copyright (C) 2016 Institute of Advanced Engineering and Science. All rights reserved.

\section{Corresponding Author:}

Shanti Wardaningsih, Department of Psychiatric Nursing, University of Muhammadiyah Yogyakarta,

Lingkar Selatan, Tamantirto Kasihan Bantul Yogyakarta Indonesia, 55183.

Email: shantiwardaningsih@gmail.com

\section{INTRODUCTION}

Empowering community as a partnership toward health service has been a method to activate community health program for at least 50 years [1]. In low- and middle-low- income countries, community health workers (CHWs) are common partners for health profession. CHWs are usually the residents selected among their community members by their communities, and help their communities to access to health services. They should be answerable to communities for their activities, and should be supported by the health system but not necessarily a part of its organizations and have shorter training than professional workers [1].

In Indonesia, CHW called Kader has been worked for three decades. They are community health volunteers for general health both of urban and rural residents, particularly working in the field of maternal and child health [2],[3] and also for health among the elderly [4]. They are important coworkers of health projects provided by the Primary Health Center (PHC), a branch of local government. PHC is located in 
every sub-district including near 30,000 residences. In cooperation of Kaders, the nurses in PHC contact with community directly and also work for case management [5].

On the other hand, as shown by World Health Organization (WHO), mental health is an essential part of health. According to the WHO survey [6], the prevalence rate of schizophrenia tends to be higher in Oceania, the Middle East, and Southeast Asia while Australia, Japan, the United States (US), and Western Europe show low prevalence rates. Those who have mental disorders have some difficulties to deal with their condition. Despite relative geographical proximity, the disability-adjusted life year (DALY) of schizophrenia in Indonesia nearly doubles that of Australia with 321,870. As for depression, there are no exact data on its prevalence rate, although WHO estimates suicide rate in Indonesia is 24 per $10^{5}$ persons. Depression as one of most leading of disabilities is often under-diagnosed and untreated. Stigma in community often prevents case-finding and treatment for these mental disorders [7]. The condition shown above is greatly affected by the people's stigma toward mental disorders. This has been already shown in two studies among the general population in Japan and the US. In the study from the US [8], a questionnaire which contained some vignettes was used to investigate the perception of the general population toward mental disorders. The questionnaire included five vignettes, those with depression, schizophrenia, alcohol dependence, drug dependence, and a trouble with neighbors. The similar tool was applied to the study for the general population in Japan [9].

Since awareness of the importance of mental disorders as a public health issue has greatly increased, and mental health has emerged on the policy agenda in many countries, these countries have developed or revised their policies, programs, and legislation system related to mental health. However, the resources provided for the prevention, treatment, and rehabilitation in mental health has remained short. Almost one thirds of countries belonging to WHO still have no special budget for mental health. Indonesia, one of developing countries, also has not put priority to the budget for mental health, whereas mental health is a huge problem in Indonesia.

Toward the above hard situation, some mental health professionals had initiative to develop a project to empower Kader in mental health work. The pioneer Kaders have been involved in mental health program of nongovernmental organization which worked in Nangroe Aceh Darusalam (NAD), a province located in Sumatra Island, Indonesia, since tsunami disaster after earthquake in 2005 [10],[11]. Kaders were conducted to help PHC nurses' activities in this program. They have some duties such as finding possible mental disorder cases, grouping them among the community, visiting their home, referring them to PHCs, motivating the community to attend to activities provided by PHC, and documentation and reporting to PHC [10],[11]. Many patients and family suffering tsunami could be helped by Kaders. According to the evaluation of NAD, Kaders detected 2,602 cases with serious mental disorders (mostly chronic psychosis), and treated them in cooperation with PHC teams. It can be provided a vital link between the patients and PHC doctors [12]. Based on the above experience, Kaders in other areas recently have been involved in community mental health program as volunteers to help PHC nurses. Since Kaders have quick access to a community, they can play an important role in the community, and support the community.

Patients with mental disorders often experience low quality of life (QOL) [13]. Although their QOL can be increased by the support from the community, it is possible that the negative experiences in meeting those who have mental health problems are confounded by stigma and poor access to mental health services [13]. It is shown that QOL among patients with mental disorders was rated good or very good by $90-92 \%$ of those who saw friends or family at least weekly, those who attended social or leisure events or facilities at least monthly and those who felt they had at least three people that they could count on. In contrast, 72-79\% of those with poorer social support rated their quality of life as high [13]. Thus, Kaders are expected to affect favorably to the perception, attitude, and support of community toward the patients with mental disorders, which, in turn, contribute to the QOL among the patients. Suwarsono [4] argued the roles and tasks of Kaders in actuating the community, although Kaders have not shown their performance maximally in this field. If this is true, it may mean that more effective training is required for Kaders to be involved in community mental health program.

Taking above into consideration, it is important to clarify the role of Kaders in community mental health and to provide them appropriate training about mental health. For this purpose, it is also important to know how Kaders actually perceive patients with mental disorders and tries to help them, and whether their perception and practice are associated with the experiences in mental health training for the Kaders. We therefore conducted an investigation on the Kaders' perceptions toward patients with mental disorders and to whom do they consult on possible patients with mental disorders. This information will be useful to determine future training program for Kaders, and also to discuss the role of CHW in other countries. The aims of this study were; 1) to identify demographic background of Kaders, 2) to compare their practice in consultation with other key persons or professionals about the cases with mental disorders with those in other 
countries, and 3) to compare the perception of the Kaders trained for mental health with those of the untrained.

\section{RESEARCH METHOD}

\subsection{Participants and Procedure}

A cross-sectional survey was conducted for Kader in the five districts of Yogyakarta Special Province, Indonesia, in June to September 2013. The author randomly chose 26 Primary Health Centers (PHCs) among the 53 PHC in the five sub-districts in the province. However, the number of PHCs in each district was proportional to the population size of the sub-district. Then, the author asked Kaders of these PHCs to participate in the present study. The inclusion criteria was being aged 18 or over, being able to read Bahasa (Indonesia language), and being active as a Kader for at least one year. The exclusion criteria was being inactive because of physical problems, or living in the location far from PHC. The last exclusion criteria were means that they could not join meeting at PHC every time and also that the authors or coworkers could not visit them in the research term. As a result, 800 Kaders was invited to the present study. They were $14.2 \%$ among 5,625 Kaders in the provinces [12].

A self-administrated questionnaire was distributed to the above samples when they got together to PHC meeting. After they completed the questionnaire, they posted it with envelope to a box prepared for this study at PHC. For the respondents living far from PHC, data collector visited the respondents to collect the questionnaire, if they are willing to respond. As a result, 619 samples (77.4\%) were collected. The above procedure was approved by the Committee for Research Safe and Ethics of Oita University of Nursing and Health Sciences, Japan, and also permitted by the above local government.

Out of them, 619 (97.6\%) responded; $97.6 \%$ were female, and 66.4\% were $35-54$ years old. Javanese ethnic were majority (97.6\%), 95.3\% were married, and 82.2\% had job.

\subsection{Questionnaire}

The questionnaires used in the present study contained six parts. In the present paper, however, only three parts (Part A, part B and part C sections) are reported, and other parts will be reported elsewhere. We did not do validity and reliability tes because the questionnaire is common used in previouse study.

Part A includes demographic variables namely sex, age, marital status, ethnicity, district where they live, occupation, income, and years of Kaders' experience. Their age was categorized into 18-24, 25-34, 3554 and 55+ years according to a previous literature [14]. Marital status was categorized into single, married, and widow. Ethnicity was categorized into non Javanese and Javanese. Among five districts, two districts (Jogja and Bantul) are in urban area, and the others are in rural area (Sleman, Gunung Kidul and Kulon Progo). Only Sleman has a general mental hospital. Occupation was categorized into full time job, part time job, and house wife. Their income was categorized into Rp 0-950,000 (low income), Rp 950,000-2,000,000 (middle income), and more than Rp 2,000,000 (high income). Years of Kaders' experience were categorized into "less than 10 years" and "over than 10 years.

Part B includes questions concerning three vignettes. Two vignettes about schizophrenia and depression were taken from MacArthur health Module of the 1996 general Social Survey, the vignette developed by the researchers piloted [15], and another vignette was made by the authors (the first vignette). The first vignette describes a woman who has schizophrenia-like symptoms, e.g. hallucination, disorientation, talking by herself, and deficit of personal hygiene. The responses to the first and second questions were discussed with the two previous studies in which almost the same questions were used. The second vignette illustrates someone with a mental disorder (talking by himself, has delusion, often do bizarre behavioral and sometimes act aggressively). The third vignette is about a man who has depression-like symptoms, e.g. lack of motivation, sleep disorder, desperate, and suicide ideation.

As for these two vignettes (second and third vignettes), respondents' perception was asked as follows [15]. Seriousness of mental illness was measured using a question with three items (very serious, somewhat serious, not very serious, or not at all serious). However, we grouped these responses into a dichotomous variable (very serious and others). The possible causes of mental illness were asked using six items, and four-point responses to each item were grouped into dichotomous variables (very likely or somewhat likely vs. not very likely or not likely). Possible problems related to mental illnesses was measured using four items, and three-point responses to each item were grouped into dichotomous variables (very likely or somewhat likely vs. not very likely or not likely). Kaders' views on ability of patients with mental disorder in making decision and managing money were measured using two questions, and four-point responses to each questions were grouped into dichotomous variables (very able or somewhat able vs. somewhat disable or disable). Kaders' views on possible violence in patients with mental illness to themselves and others were measured using two questions, and four-point responses to each question were 
grouped into dichotomous variables (very able or somewhat able vs. somewhat disable or disable). Kaders' perception of the possibility for the patients with mental disorder to be improved by themselves or by treatment was measured using two questions, and four-point responses to each questions were grouped into dichotomous variables (very likely or somewhat likely vs. not very likely or not likely).

The question on the first vignette was concerned with another person with possible mental disorder. The Kaders were asked with whom they will consult the patients. The possible multiple choices were society leaders, community health centers, psychiatric hospitals, and alternative treatment.

In Part C, the presence or absence of experiences in Kaders training about mental health was dichotomously asked. We compare the result of this study with a study in Nagasaki (Japan) by Nakane [16], and the study in the United States [8].

\subsection{Data Analysis}

We examined the association of the perception with demographic data (gender, age, ine, marital status, ethnic, occupation, location, and years of Kader experience), using chi $^{2}$-test. Next, their responses were compared among the trained and untrained Kaders for mental health, using chi $^{2}$-test and odds ratio (OR). All the analyses were conducted with fisher exact probability test using SPSS Statistic 17 for Windows statistical package.

\section{RESULTS AND ANALYSIS}

\subsection{Kaders' perception toward mental disorders and international differences}

In the community health system in Indonesia, Primary Health Center (PHC) depends on Kader as CHW, and Kaders play a role of facilitators for community to reach health services [3]. The Kaders' performance has been particularly visible in the field of maternal and child health. In Indonesia, however, $90 \%$ of patients with mental disorders do not receive even basic mental health care [17]. Case-finding for them and their prognosis are often affected by the perception and attitude of society toward mental disorders, which is highly dependent on their knowledge toward mental disorders [18]. Kaders are expected to take a role not only to directly help patients, but also to indirect affect the above perception and attitude of individuals in community [18]. However, Kaders have not shown their performance maximally for community mental health except some regions which experienced a terrible earthquake and tsunami [4].

The Indonesia national government therefore enacted Mental Health Law in August 2014, which is expected to contribute to the spread of correct knowledge concerning mental disorders. This law, however, had not established yet when the present study was conducted.

The first finding of the present study is concerning the comparison in the perception toward mental disorders among Kaders and the general population in Japan or the US [8],[9]. A part of Kaders' knowledge and perception for mental disorders appear inadequate, in comparison with the previous reports from the above two countries. The Kaders seem pessimistic about the possibility of recovery and the ability of making decision for treatment and managing money among the patients. This appears correct if a patient is at acute stage, although this cannot be correct for all the patients with schizophrenia or depression. It suppose that Kaders have too much optimistic or pessimistic view, this might make them miss to find patients to be treated, or makes them give up in helping recovery of the patients. Since resources of mental health services are in short in Indonesia, the general information about mental disorders has not been well known even among Kaders, and they rarely see the patients get well. It is therefore reasonable for them to be pessimistic as above. Furthermore family members in Javanese is so close each other [19],[20] that patients easily get help for making decision from their family in general. This Javanese culture background may help some patients depend on their family, which is close to a kind of paternalism.

The Kaders, however, showed some advantages in their perception toward mental disorders. They believe that patients with mental disorders less violent to other, that is quite different with result of the previous study namely in Japan and the US [8],[9], and this, in turn, may contribute to build up good relationships between the patients and the Kaders. The Kaders also perceived lower risk of suicide for these patients, compared with the general population in Japan and the US. This may reflect to the fact that suicide mortality is lower in Indonesia [20], based on the Moslem background than Japan and the US.

\subsection{Consultation concerning patients with mental disorders}

The Kaders as representative of the general residents generally consult with the PHC about the cases of mental disorders in their community (Table 1), which seems a good choice. Their second choice was consultation with community leaders. This seems reasonable in Indonesian and Asia culture which encourages persons helping each other [20],[21]. Compared with the general population in the other two countries, it was rare for the Kaders to consult patients with mental disorders with alternative therapist or 
religious leaders. However, this is still common in the province which has engaged Kaders in mental health services. Alternative therapy is so expensive in Indonesia that Kaders, community health volunteers, will hesitate to access these therapies. These results seem to be based on the training for Kaders which had focused on maternal and child health for a long time.

Kaders who lived in Sleman district most choose to consult with mental psychiatric hospitals. Since Yogyakarta has only one mental hospital, in the future the local government in Yogyakarta must make a referral system for discharged patients from the hospital to PHCs whole of districts in Yogyakarta.

Table 1. Consultants for possible patients with a mental disorder

\begin{tabular}{|c|c|c|c|}
\hline Consultants & Indonesia & $\operatorname{Japan}^{15)}$ & The US ${ }^{14)}$ \\
\hline Community leaders & $28.8 \%$ & - & - \\
\hline Family and friends & - & - & $50.9 \%$ \\
\hline $\begin{array}{l}\text { Public Health Center or nurse or general physician (non } \\
\text { specialist) }\end{array}$ & $40.9 \%$ & $31.4 \%$ & $16.9 \%$ \\
\hline \multicolumn{4}{|l|}{ Mental hospital (Psychiatrist) } \\
\hline Mental hospital & $28.8 \%$ & $56.1 \%$ & $6.5 \%$ \\
\hline Psychiatrist & & & $7.6 \%$ \\
\hline Alternative medicine/supra-natural, religious leader & $1.3 \%$ & $7.5 \%$ & $10.2 \%$ \\
\hline Police officer & - & $4.7 \%$ & - \\
\hline \multicolumn{4}{|l|}{ Take medicine } \\
\hline - $\quad$ Non prescription medicine & - & - & $0.2 \%$ \\
\hline - $\quad$ Prescription medicine & & & $6.5 \%$ \\
\hline Therapist ( counselor, psychologist) & - & - & $10.4 \%$ \\
\hline Total & $100 \%$ & $100 \%$ & $100 \%$ \\
\hline
\end{tabular}

\subsection{Kader experience in training about mental health}

As far as Table 2 is concerned, mental health training for Kaders has almost no influence on their perception toward mental disorders, especially to issue of schizophrenia.

Table 2. Demographic background of trained and untrained Kaders for mental health

\begin{tabular}{|c|c|c|c|c|c|}
\hline \multirow{2}{*}{ Variables } & \multirow{2}{*}{ Items } & \multicolumn{2}{|c|}{ Training } & \multirow{2}{*}{ N (\%) } & \multirow{2}{*}{ test $^{1}$} \\
\hline & & Present & Absent & & \\
\hline \multirow{2}{*}{$\begin{array}{l}\text { Years of Kader's } \\
\text { experience }\end{array}$} & Short (<10yrs) & 83 (22.96\%) & 295 (78.04\%) & 378 (100\%) & \multirow{2}{*}{$\mathrm{P}<0.001$} \\
\hline & Long ( $>=10 y r s)$ & 89 (43.84\%) & $114(56.16 \%)$ & 203 (100\%) & \\
\hline \multirow{2}{*}{ Area } & Rural & 100 (33.22\%) & 201 (66.77\%) & 301 (100\%) & \multirow{2}{*}{ NS } \\
\hline & Urban & 81 (26.29\%) & 227 (73.70\%) & 308 (100\%) & \\
\hline Educational & Low level & 50 (25.51\%) & 146 (74.49\%) & 196 (100\%) & \multirow{2}{*}{ NS } \\
\hline background & High level & $130(31.71 \%)$ & $280(68.29 \%)$ & $410(100 \%)$ & \\
\hline
\end{tabular}

${ }^{1}$ Fisher's exact probability test

$\mathrm{N}=619$, missing cases was excluded from tabulation.

However, only among the Kaders with long experiences, the trained Kaders seem to be more sensitive to possible mental disorders than the untrained (Table 3). Mental health training for Kaders is usually shorter than two days, whereas the original guidance CMHN Intermediate Course proposes at less 3 days (80 hours) [11]. The contents of the current mental health training consist of definition, sign, and symptoms of mental disorders, and how to help the patients. Based on the results of the present study, it is needed to add the contents such as causes of mental disorders and possibility of recovery to the program. Correct knowledge about the causes of mental disorders can reduce the stigma against mental illness [17]. 
Table 3. Perception toward mental disorders and training in mental health

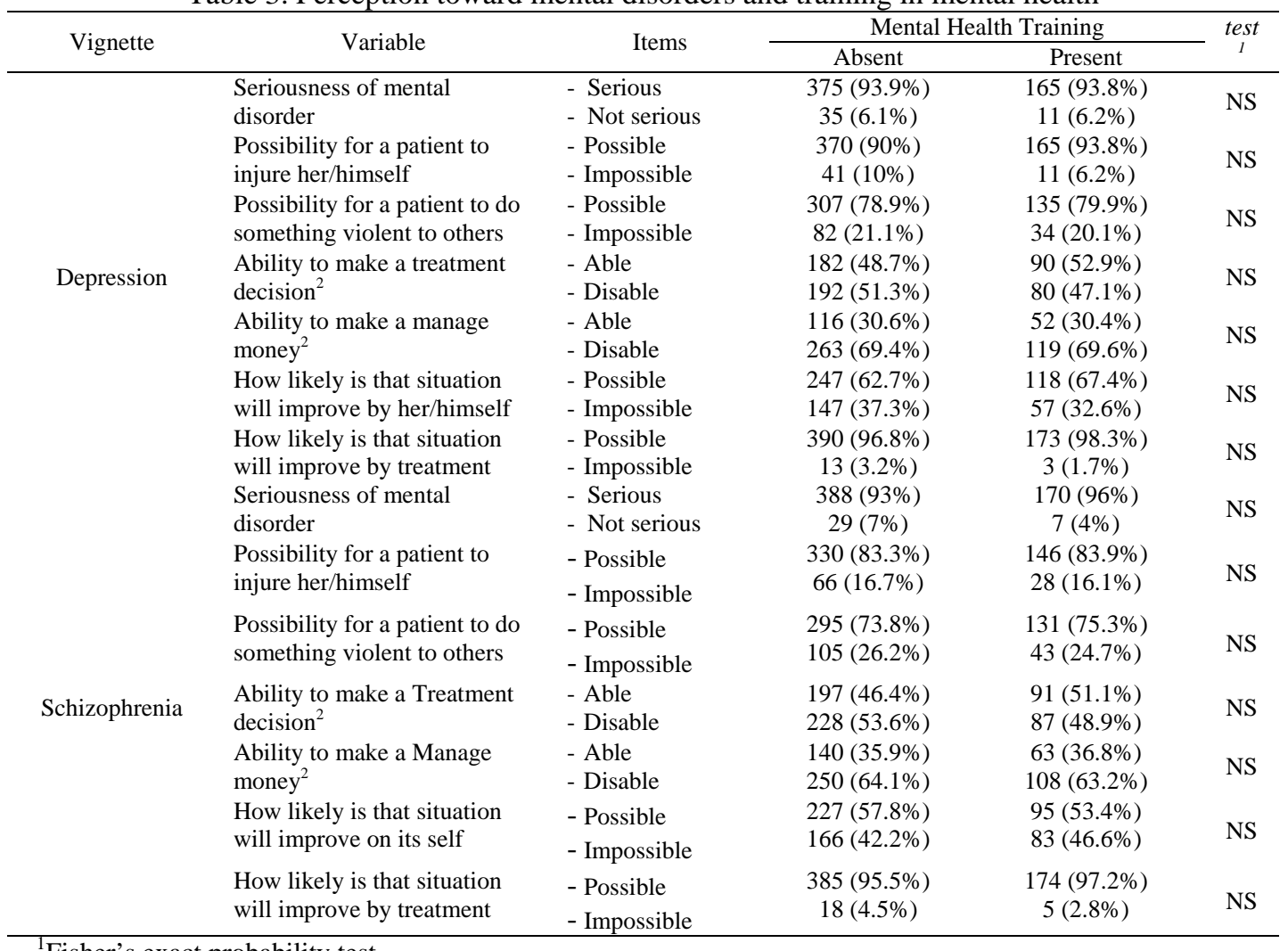

${ }^{1}$ Fisher's exact probability test

${ }^{2}$ Respondents who answer “don’t know” are excluded from tabulation

In contrast, whether a Kader had ever met the actual cases with mental disorders like the third vignettes were associated with the in views on mental health (Table 4). These results suggest that actual experiences in meeting the cases contribute to improve Kaders' perception concerning mental disorders better than the previous mental health training. Stigma generally develops by the interaction between three dimensional axis, perspective, identity, and reaction [22]. If the experiences in meeting the cases improve the Kaders' information and knowledge to change their perception toward mental disorders, this will help to reduce their stigma to the people with mental disorders. This possibility should be taken into consideration to plan the future mental health training for Kaders. 
Table 4. Association of mental health training with perception by years of Kaders experience

\begin{tabular}{|c|c|c|c|c|c|c|c|c|}
\hline \multirow{2}{*}{ Vignette } & \multirow{2}{*}{ Variable } & \multirow{2}{*}{$\begin{array}{c}\text { Yrs Kaders }^{1} \\
\text { Training }^{2} \\
\end{array}$} & \multicolumn{2}{|c|}{ Short (10 yrs) } & \multirow{2}{*}{$P^{3}$} & \multicolumn{2}{|c|}{ Long $(>=10$ yrs $)$} & \multirow{2}{*}{$P^{3}$} \\
\hline & & & Absent & Present & & Absent & Present & \\
\hline \multirow{7}{*}{ Depression } & $\begin{array}{l}\text { Seriousness of } \\
\text { mental disorder }\end{array}$ & $\begin{array}{l}\text { - Serious } \\
\text { - Not serious }\end{array}$ & $\begin{array}{c}262(93.6 \%) \\
18(6.4 \%)\end{array}$ & $\begin{array}{l}70(88.6 \%) \\
9(11.4 \%)\end{array}$ & NS & $\begin{array}{l}97(87.4 \%) \\
14(12.6 \%)\end{array}$ & $\begin{array}{c}85(97.7 \%) \\
2(2.3 \%)\end{array}$ & $0.01^{4}$ \\
\hline & $\begin{array}{l}\text { Possibility for a } \\
\text { patient to injure } \\
\text { her/himself }\end{array}$ & $\begin{array}{l}\text { - Possible } \\
\text { - Impossible }\end{array}$ & $\begin{array}{c}261(91.6 \%) \\
24(8.4 \%)\end{array}$ & $\begin{array}{c}76(93.8 \%) \\
5(6.2 \%)\end{array}$ & NS & $\begin{array}{l}93(86.9 \%) \\
14(13.1 \%)\end{array}$ & $\begin{array}{c}81(94.2 \%) \\
5(5.8 \%)\end{array}$ & NS \\
\hline & $\begin{array}{l}\text { Possibility for a } \\
\text { patient to do } \\
\text { something } \\
\text { violent to others }\end{array}$ & $\begin{array}{l}\text { - Possible } \\
\text { - Impossible }\end{array}$ & $\begin{array}{c}220(82.4 \%) \\
47(17.6 \%)\end{array}$ & $\begin{array}{l}67(84.8 \%) \\
12(15.2 \%)\end{array}$ & NS & $\begin{array}{l}74(71.8 \%) \\
29(28.2 \%)\end{array}$ & $\begin{array}{l}60(74.1 \%) \\
21(25.9 \%)\end{array}$ & NS \\
\hline & $\begin{array}{l}\text { Ability to make } \\
\text { a treatment } \\
\text { decision }^{2}\end{array}$ & $\begin{array}{l}\text { - Able } \\
\text { - Disable }\end{array}$ & $\begin{array}{l}135(52.3 \%) \\
123(47.7 \%)\end{array}$ & $\begin{array}{l}47(61.0 \%) \\
30(39.0 \%)\end{array}$ & NS & $\begin{array}{l}36(37.1 \%) \\
61(62.9 \%)\end{array}$ & $\begin{array}{l}41(47.7 \%) \\
45(52.3 \%)\end{array}$ & NS \\
\hline & $\begin{array}{l}\text { Ability to make } \\
\text { a manage } \\
\text { money }^{2}\end{array}$ & $\begin{array}{l}\text { - Able } \\
\text { - Disable }\end{array}$ & $\begin{array}{c}85(33.3 \%) \\
170(66.7 \%)\end{array}$ & $\begin{array}{l}24(32.4 \%) \\
50(67.6 \%)\end{array}$ & NS & $\begin{array}{l}26(24.8 \%) \\
79(75.2 \%)\end{array}$ & $\begin{array}{l}27(30.7 \%) \\
61(69.3 \%)\end{array}$ & NS \\
\hline & $\begin{array}{l}\text { How likely is } \\
\text { that situation } \\
\text { will improve by } \\
\text { her/himself }\end{array}$ & $\begin{array}{l}\text { - Possible } \\
\text { - Impossible }\end{array}$ & $\begin{array}{c}220(82.4 \%) \\
47(17.6 \%)\end{array}$ & $\begin{array}{l}67(84.8 \%) \\
12(15.2 \%)\end{array}$ & NS & $\begin{array}{l}74(71.8 \%) \\
29(28.2 \%)\end{array}$ & $\begin{array}{l}60(74.1 \%) \\
21(25.9 \%)\end{array}$ & NS \\
\hline & $\begin{array}{l}\text { How likely is } \\
\text { that situation } \\
\text { will improve by } \\
\text { treatment }\end{array}$ & $\begin{array}{l}\text { - Possible } \\
\text { - Impossible }\end{array}$ & $\begin{array}{c}269(96.8 \%) \\
9(3.2 \%)\end{array}$ & $\begin{array}{c}81(100 \%) \\
0(0.0 \%)\end{array}$ & NS & $\begin{array}{c}102(96.2 \%) \\
4(3.8 \%)\end{array}$ & $\begin{array}{c}83(96.5 \%) \\
3(3.6 \%)\end{array}$ & NS \\
\hline \multirow{7}{*}{ Schizophrenia } & $\begin{array}{l}\text { Seriousness of } \\
\text { mental disorder }\end{array}$ & $\begin{array}{ll}\text { - } & \text { Serious } \\
\text { - } & \text { Not serious } \\
\end{array}$ & $\begin{array}{c}275(95.2 \%) \\
14(4.8 \%) \\
\end{array}$ & $\begin{array}{c}77(96.3 \%) \\
3(3.8 \%)\end{array}$ & NS & $\begin{array}{l}95(87.2 \%) \\
14(12.8 \%)\end{array}$ & $\begin{array}{c}84(95.5 \%) \\
4(4.5 \%) \\
\end{array}$ & $0.04^{5}$ \\
\hline & $\begin{array}{l}\text { Possibility for a } \\
\text { patient to injure } \\
\text { her/himself }\end{array}$ & $\begin{array}{l}\text { - Possible } \\
\text { - Impossible }\end{array}$ & $\begin{array}{c}237(86.5 \%) \\
37(3.5 \%)\end{array}$ & $\begin{array}{l}65(81.3 \%) \\
15(18.7 \%)\end{array}$ & NS & $\begin{array}{l}84(80 \%) \\
21(20 \%)\end{array}$ & $\begin{array}{l}74(87.1 \%) \\
11(12.9 \%)\end{array}$ & NS \\
\hline & $\begin{array}{l}\text { Possibility for a } \\
\text { patient to do } \\
\text { something } \\
\text { violent to others }\end{array}$ & $\begin{array}{l}\text { - Possible } \\
\text { - Impossible }\end{array}$ & $\begin{array}{c}215(76.2 \%) \\
67(23.8 \%)\end{array}$ & $\begin{array}{l}58(72.5 \%) \\
22(27.5 \%)\end{array}$ & NS & $\begin{array}{l}66(66.7 \%) \\
33(33.3 \%)\end{array}$ & $\begin{array}{l}66(77.6 \%) \\
19(22.4 \%)\end{array}$ & NS \\
\hline & $\begin{array}{l}\text { Ability to make } \\
\text { a treatment } \\
\text { decision }^{2}\end{array}$ & $\begin{array}{l}\text { - Able } \\
\text { - Disable }\end{array}$ & $\begin{array}{l}140(47.6 \%) \\
154(52.4 \%)\end{array}$ & $\begin{array}{l}46(56.1 \%) \\
36(43.9 \%)\end{array}$ & NS & $\begin{array}{l}45(40.2 \%) \\
67(59.8 \%)\end{array}$ & $\begin{array}{l}43(48.9 \%) \\
45(51.1 \%)\end{array}$ & NS \\
\hline & $\begin{array}{l}\text { Ability to make } \\
\text { a manage } \\
\text { money }^{2}\end{array}$ & $\begin{array}{ll}\text { - } & \text { Able } \\
\text { - Disable }\end{array}$ & $\begin{array}{l}103(38.6 \%) \\
164(61.4 \%)\end{array}$ & $\begin{array}{l}36(45.0 \%) \\
44(55.0 \%)\end{array}$ & NS & $\begin{array}{l}30(28.8 \%) \\
74(71.2 \%)\end{array}$ & $\begin{array}{l}25(29.4 \%) \\
60(70.6 \%)\end{array}$ & NS \\
\hline & $\begin{array}{l}\text { How likely is } \\
\text { that situation } \\
\text { will improve by } \\
\text { her/himself }\end{array}$ & $\begin{array}{l}\text { - Possible } \\
\text { - Impossible }\end{array}$ & $\begin{array}{l}159(58.9 \%) \\
111(41.1 \%)\end{array}$ & $\begin{array}{l}51(60.7 \%) \\
32(39.3 \%)\end{array}$ & NS & $\begin{array}{l}58(55.2 \%) \\
47(44.8 \%)\end{array}$ & $\begin{array}{l}41(47.7 \%) \\
45(52.3 \%)\end{array}$ & NS \\
\hline & $\begin{array}{l}\text { How likely is } \\
\text { that situation } \\
\text { will improve by } \\
\text { treatment }\end{array}$ & $\begin{array}{l}\text { - Possible } \\
\text { - Impossible }\end{array}$ & $\begin{array}{c}266(96.4 \%) \\
10(3.6 \%)\end{array}$ & $\begin{array}{c}83(100 \%) \\
0(0.0 \%)\end{array}$ & NS & $\begin{array}{c}103(93.6 \%) \\
7(6.4 \%)\end{array}$ & $\begin{array}{c}82(94.3 \%) \\
5(5.7 \%)\end{array}$ & NS \\
\hline
\end{tabular}

Respondents who answer “don’t know” are excluded from tabulation. ${ }^{1}$ Years of Kader experience. ${ }^{2}$ Experience in mental health training. ${ }^{3}$ Fisher's exact probability test. ${ }^{4}$ Compared with the absent group, the OR (95\% confidence interval, CI) of perceiving not serious was $0.16(0.04-0.72)$ in the present group. ${ }^{5}$ Compared with the absent group, the OR (95\% CI) of perceiving not serious was $0.32(0.10-1.00)$ in the present group.

The above results (Table 5) shows the need to revise the contents of mental health training for Kaders. They are expected to know mental and behavioral symptoms suggesting the need to be treated, causes of major mental disorders, and possible prognosis of mental disorders. They are also expected to take appropriate action for treatment and rehabilitation, based on appropriate assessment, and contributes to preventive measures against mental disorders, if possible. For these purpose the contents of mental health training program should be composed for these purposes from a practical viewpoint. Too much difficult knowledge and terminology are not required. In this context, Japan can be a good example; to replace schizophrenia with easier terminology in Japanese (2001) was efficient to reduce stigma for patients with schizophrenia [23]. It is also desirable that as young Kaders as possible should be newly recruited, because young generation is more accessible to correct information about mental health, and able to continue to participate in mental health program. 
Table 5. Experience in meeting cases with mental disorders and perception toward mental disorders

\begin{tabular}{|c|c|c|c|c|c|}
\hline \multirow{2}{*}{ Vignette } & \multirow{2}{*}{ Variables } & \multirow{2}{*}{ Items } & \multicolumn{2}{|c|}{ Experience } & \multirow[t]{2}{*}{$P^{1}$} \\
\hline & & & Absent & Present & \\
\hline \multirow{7}{*}{ Depression } & Seriousness of mental disorder & $\begin{array}{l}\text { - } \text { Serious } \\
\text { - } \text { Not serious }\end{array}$ & $\begin{array}{c}287(89.9 \%) \\
32(10.1 \%)\end{array}$ & $\begin{array}{c}255(94.8 \%) \\
14(5.2 \%)\end{array}$ & $0.03^{3}$ \\
\hline & $\begin{array}{l}\text { Possibility for a patient to injure } \\
\text { her/himself }\end{array}$ & $\begin{array}{ll}\text { - Possible } \\
\text { - Impossible }\end{array}$ & $\begin{array}{c}285(89.6 \%) \\
33(10.4 \%)\end{array}$ & $\begin{array}{c}251(92.6 \%) \\
20(7.4 \%)\end{array}$ & NS \\
\hline & $\begin{array}{l}\text { Possibility for a patient to do } \\
\text { something violent to others }\end{array}$ & $\begin{array}{ll}\text { - } & \text { Possible } \\
\text { - } & \text { Impossible } \\
\end{array}$ & $\begin{array}{c}238(77.8 \%) \\
68(22.2 \%) \\
\end{array}$ & $\begin{array}{c}206(81.1 \%) \\
48(10.9 \%)\end{array}$ & NS \\
\hline & $\begin{array}{l}\text { Ability to make a treatment } \\
\text { decision }^{2}\end{array}$ & $\begin{array}{l}\text { - Able } \\
\text { - Disable } \\
\end{array}$ & $\begin{array}{l}149(49.3 \%) \\
153(50.7 \%)\end{array}$ & $\begin{array}{l}127(51.8 \%) \\
118(48.2 \%) \\
\end{array}$ & NS \\
\hline & $\begin{array}{l}\text { Ability to make a manage } \\
\text { money }^{2}\end{array}$ & $\begin{array}{l}\text { - Able } \\
\text { - Disable }\end{array}$ & $\begin{array}{c}95(31.1 \%) \\
210(58.9 \%)\end{array}$ & $\begin{array}{c}73(29.4 \%) \\
175(70.6 \%)\end{array}$ & NS \\
\hline & $\begin{array}{l}\text { How likely is that situation will } \\
\text { improve by her/himself }\end{array}$ & $\begin{array}{ll}\text { - Possible } \\
\text { - } \text { Impossible }\end{array}$ & $\begin{array}{l}180(58.1 \%) \\
130(41.9 \%)\end{array}$ & $\begin{array}{c}186(70.7 \%) \\
77(29.3 \%) \\
\end{array}$ & $0.00^{4}$ \\
\hline & $\begin{array}{l}\text { How likely is that situation will } \\
\text { improve by treatment }\end{array}$ & $\begin{array}{l}\text { - Possible } \\
\text { - Impossible }\end{array}$ & $\begin{array}{c}309(96.5 \%) \\
8(3.5 \%) \\
\end{array}$ & $\begin{array}{c}258(97.7 \%) \\
8(2.3 \%) \\
\end{array}$ & NS \\
\hline \multirow{7}{*}{ Schizophrenia } & Seriousness of mental disorder & $\begin{array}{l}\text { - } \text { Serious } \\
\text { - } \text { Not serious }\end{array}$ & $\begin{array}{c}297(92.5 \%) \\
24(7.5 \%) \\
\end{array}$ & $\begin{array}{c}264(95.7 \%) \\
12(4.3 \%) \\
\end{array}$ & NS \\
\hline & $\begin{array}{l}\text { Possibility for a patient to injure } \\
\text { her/himself }\end{array}$ & $\begin{array}{ll}\text { - } & \text { Possible } \\
\text { - } & \text { Impossible } \\
\end{array}$ & $\begin{array}{c}257(82.4 \%) \\
55(17.6 \%) \\
\end{array}$ & $\begin{array}{c}220(84.6 \%) \\
40(15.4 \%) \\
\end{array}$ & NS \\
\hline & $\begin{array}{l}\text { Possibility for a patient to do } \\
\text { something violent to others }\end{array}$ & $\begin{array}{ll}\text { - Possible } \\
\text { - Impossible }\end{array}$ & $\begin{array}{c}242(77.1 \%) \\
72(22.9 \%) \\
\end{array}$ & $\begin{array}{l}184(70.5 \%) \\
77(29.5 \%)\end{array}$ & NS \\
\hline & $\begin{array}{l}\text { Ability to make a treatment } \\
\text { decision }^{2}\end{array}$ & $\begin{array}{l}\text { - Able } \\
\text { - Disable } \\
\end{array}$ & $\begin{array}{l}149(45.7 \%) \\
177(54.3 \%) \\
\end{array}$ & $\begin{array}{l}139(49.4 \%) \\
141(50.1 \%) \\
\end{array}$ & NS \\
\hline & $\begin{array}{l}\text { Ability to make a manage } \\
\text { money }^{2}\end{array}$ & $\begin{array}{l}\text { - Able } \\
\text { - Disable } \\
\end{array}$ & $\begin{array}{c}95(31.1 \%) \\
210(68.9 \%) \\
\end{array}$ & $\begin{array}{l}108(41.9 \%) \\
150(58.1 \%) \\
\end{array}$ & $0.01^{5}$ \\
\hline & $\begin{array}{l}\text { How likely is that situation will } \\
\text { improve by her/himself }\end{array}$ & $\begin{array}{l}\text { - Possible } \\
\text { - Impossible }\end{array}$ & $\begin{array}{l}158(50.8 \%) \\
153(49.2 \%)\end{array}$ & $\begin{array}{c}165(62.9 \%) \\
97(37.1 \%) \\
\end{array}$ & $0.00^{6}$ \\
\hline & $\begin{array}{l}\text { How likely is that situation will } \\
\text { improve by treatment }\end{array}$ & $\begin{array}{ll}\text { - Possible } \\
\text { - Impossible }\end{array}$ & $\begin{array}{c}304(95.9 \%) \\
13(4.1 \%)\end{array}$ & $\begin{array}{c}257(95.2 \%) \\
10(4.8 \%) \\
\end{array}$ & NS \\
\hline
\end{tabular}

${ }^{1}$ Fisher's exact probability test. ${ }^{2}$ Respondents who answered “don't know” are excluded from tabulation. ${ }^{3}$ Compared with the absent group, the OR (95\% CI) of perceiving not serious was 0.49 (0.26-0.93) in the present group. ${ }^{4}$ Compared with the absent group, the OR (95\% CI) of perceiving impossible was 0.57 (0.41-0.81) in the present group. ${ }^{5}$ Compared with the absent group, the OR (95\% CI) of perceiving disable was $0.63(0.45-0.88)$ in the present group. ${ }^{6}$ Compared with the absent group, the OR (95\% CI) of perceiving impossible was $0.61(0.44-0.84)$ in the present group.

\section{CONCLUSION}

Some limitation of this study also should be discussed. Study area was limited to Yogyakarta province. We are satisfied with high response rate (77\%), although some Kaders did not give answers to our questionnaires. Since study design was cross-sectional, we cannot determine exact causal relationship for the correlation observed in our results.

Regardless of these limitations, the obtained results show what should be changed in future training program on mental health for Kaders. We need to modify the training program and examine its efficiency in future. Furthermore, the implementation of mental health law and policy should be support and provide an adequate budget to develop and encourage the Kaders quality.

\section{ACKNOWLEDGEMENTS}

We would like to express our appreciation for all the Community Health Workers (Kaders) in this study, the local government in Yogyakarta, Oita University of Nursing and Health Sciences, Directorate General of Higher Education Republic Indonesia, and University of Muhammadiyah Yogyakarta. This study was supported by a research grant from Oita University of Nursing and health Sciences and University of Muhammadiyah Yogyakarta. The authors have no conflict of interest to declare.

\section{REFERENCES}

[1] World Health Organization, "Evidence and Information for Policy: Department of Human Resources for Health", Community health worker: what do we know about them?, Geneva, 2007.

[2] Zulkifli A., Thaha AR., Hadju V., Thaha R., "Effects of learning organization on cadre performance in conducting child growth surveillance in Bone District, South Sulawesi”, In Proceeding of Conference of Asia-Pasific Academic Consortium for Public Health on Kagawa: 22-25 November, Japan, pp. 220, 2007.

[3] Iswarawanti, DN., "Posyandu cadres: their roles and challenges in empowerment for improving children nutritional status in Indonesia", Jurnal Manajemen Pelayanan Kesehatan, vol. 13, pp. 169 -173, 2010. 
[4] Suwarsono, "Analysis on roles and tasks role of health kader in implementation of elderly's integrated service post (Posyandu) in working area of Temanggung district, Central of Java, Master Thesis, 2007.

[5] Department of Health-Social Welfare, "Indonesian national mental health policy”, Republic of Indonesia, Jakarta, 2001.

[6] World Health Organization, "Estimated total DALYs (per 100,000), by cause and WHO member state", Department of measurement and health information, Geneva, 2009.

[7] Kaligis, Fransiska, et. al., "How depression is treated in Indonesia”, Symposium of Psychiatria et Neurologia Japonica 106, Japan, 2011.

[8] Indiana consortium for mental health services research, “Americans' views of mental health and illness at century's end: continuity and change”, Bloomington, 1996.

[9] Yamazaki Y., et.al., "Kokoro no yamai eno manazashi to stigma (Views on mental health disorders and stigma)", Akashi Pub, Tokyo, 2012.

[10] Keliat, BA., et. al., “Keperawatan kesehatan komunitas: CMHN (Basic Course)”, Jakarta, EGC Press, 2011.

[11] Keliat, BA, et. al., "Manajemen keperawatan psikososial and kader kesehatan jiwa: CMHN (Intermediet Course)", Jakarta, EGC Press, 2011.

[12] Health Service Executive, "Mental health in Irlandia: awareness and attitudes”, 2007. ISBN 978-0-9553854-1.

[13] Prasetiyawan, et. al., "Mental health model of care programmes after the tsunami in Aceh, Indonesia", Int Rev Psychiatry, vol/issue: 18(6), pp. 559-62, 2006.

[14] Dinas Kesehatan Daerah Istimewa Yogyakarta, "Profil promosi kesehatan Daerah Istimewa Yogyakarta", Yogyakarta, 2011.

[15] Blumberg, Linda J., "Age dating under comprehensive health care reform: implications for coverage, costs, and household financial burden”, New Jersey, 2009.

[16] Nakane Y., "Progress in social psychiatry in Japan: an approach to psychiatric epidemiology”, Springer, Tokyo, 2010.

[17] Armstrong G., Kermode M., Raja S., Suja S., Chandra P., Jorm AF., “A mental health training program for community health workers in India: impact on knowledge and attitudes”, International Journal of Mental Health Systems, vol. 5, pp. 17, 2011.

[18] Salve H., et. al., "Perception and attitude towards mental illness in the urban community in south delhi-community based study”, Indian J Psychol Med, vol/issue: 35(2), pp. 154-159, 2013.

[19] Kurihara T., Kato M., Sakamoto S., Reverger R., Kitamura T., "Public attitude toward the mentally ill: a crosscultural study between Bali and Tokyo”, Psychiatry and Clinical Neurosciences, vol. 54, pp. 547-552, 2000.

[20] Subandi MA., "Family expressed emotion in Javanese culture”, Cult Med Psychiatry, vol/issue: 35(3), pp. 331-346, 2011.

[21] Ito H., Setoya Y., Suzuki Y., "Lessons learned in developing community mental health care in east and south east asia”, World Psychiatry, vol. 11, pp. 186-190, 2012.

[22] Das S., Phookun HR., "Knowledge, attitude, perception and belief (K.A.P.B) of patients' relatives towards mental illness: association with clinical and social demographic characteristics”, Delhi Psychiatry Journal, vol/issue: 16(1), pp. 98-109, 2013.

[23] Sato M., "Renaming schizophrenia: a Japanese perspective”, World Psychiatry, vol. 5, pp. 1, 2006. 